\title{
Synthesis and Pharmacological Analysis of High Affinity Melatonin Receptor Ligands
}

\author{
Guo-Hua Chu, ${ }^{a}$ Paula A. WitT-Enderby, ${ }^{b}$ Marla Jones, ${ }^{b}$ and Pui-Kai Li ${ }^{*, c}$ \\ Department of Medicinal Chemistry and Pharmaceutics ${ }^{a}$ and Department of Pharmacology and Toxicology, ${ }^{b}$ Mylan \\ School of Pharmacy, Duquesne University, Pittsburgh, PA, 15282, U.S.A. and Division of Medicinal Chemistry and \\ Pharmacognosy, College of Pharmacy, The Ohio State University, ${ }^{c}$ Columbus Ohio, 43210, U.S.A.
}

Received August 13, 2001; accepted November 21, 2001

We report the synthesis and radioligand binding analysis of a series of naphthalenic melatonin receptor ligands, $N$-[2-(7-alkoxy-2-methoxy-1-naphthyl)ethyl]propionamide. This series of ligands exhibits subpicomolar binding affinity to both $\mathrm{MT}_{1}$ and $\mathrm{MT}_{2}$ melatonin receptors expressed in chinese hamster ovary (CHO) cells.

Key words melatonin; $\mathrm{MT}_{1}, \mathrm{MT}_{2}$ receptors/receptor binding; naphthalenic melatonin receptor ligands

Melatonin is a hormone that is involved in a variety of physiological and pathological responses such as circadian rhythms, retinal physiology, seasonal breeding, cardiovascular regulation, anti-oxidative activity and oncogenesis. ${ }^{1-7)}$ Except anti-oxidative activity, melatonin may mediate its effect in vivo through melatonin receptors. Presently, two human melatonin receptor subtypes exist and are now defined as either the $\mathrm{MT}_{1}^{8)}$ (formerly known as the $\mathrm{Mel}_{1 \mathrm{a}}$ receptor) ${ }^{9)}$ and the $\mathrm{MT}_{2}{ }^{8)}$ (formerly known as the $\mathrm{Mel}_{1 \mathrm{~b}}$ receptor) ${ }^{10)}$ The ability of melatonin or melatonin-like compounds to bind to and elicit physiological responses is dependent upon specific interactions between the ligand and receptor. The elucidation of the components of melatonergic ligands that are involved in high-affinity binding is becoming clearer. Currently, what we know is that the indole ring of melatonin is not crucial for melatonin receptor recognition. For instance, the naphthalene ring ${ }^{11-20)}$ can serve as a bioisostere of the indole nucleus of melatonin and analog 2 was reported to have equivalent affinity to melatonin for melatonin receptors in ovine pars tuberalis. ${ }^{11)}$ In addition, other groups such as amidotetralin, ${ }^{21)}$ methoxychroman, ${ }^{22)}$ amido indane, ${ }^{23)}$ benzofuran, ${ }^{18,24)}$ benzothiophene ${ }^{18,24)}$ and quinoline ${ }^{25)}$ can serve as a bioisostere of the indole nucleus of melatonin. Langlois et $a l$. reported that the addition of a 2-methoxy group (OMe) to compound 2 to form 3 results in an order of magnitude increase in receptor affinity over compound 2 (Fig. 1). ${ }^{12)}$ It was postulated that the 2-OMe group binds to the accessory binding site of the receptor. Recently, we reported the synthesis and receptor binding studies of several analogs of $\mathbf{3}$ (general structure 4) with the substituents either hydrophilic or hydrophobic in nature with different sizes. ${ }^{16)}$ Preliminary results show that analogs with smaller substituents in R, irrespective of their hydrophilic or hydrophobic nature, exhibit higher affinity for melatonin receptors when compared to those with larger substituents. We postulate that the close proximity of the amidoethyl side chain may be interfering with the conformation of the substituent on 2-position in $\mathbf{4}$ (Fig. 1). Thus, to determine the validity of this hypothesis, the amidoethyl group was transferred from $\mathrm{C} 1$ to $\mathrm{C} 8$ to eliminate the steric interference between the amidoethyl group and the substituent on 2-position in compound 4 . The transfer should not affect the affinity of the ligands for the melatonin receptor as shown by Langlois et al. in which compound $5\left(K_{\mathrm{i}}=0.67 \mathrm{~nm}\right)$ has the same affinity for melatonin receptors in chicken brain when compared to compound $\mathbf{2}$ $\left(K_{\mathrm{i}}=0.54 \mathrm{~nm}\right)\left(\right.$ Fig. 1) ${ }^{12)}$ After eliminating the steric interference of the amidoethyl side chain and the substituents on 2position, we then synthesized compounds $\mathbf{6 - 1 0}$ with the substituents on 7-position of varying sizes.

\section{Results and Conclusions}

Chemistry The synthesis of compounds $\mathbf{6 - 1 0}$ is summarized in Fig. 2. Monobenzylation of 2,7-dihydroxynaphthalene 11 by reaction with 1 eq of benzyl bromide to form $12(39 \%)$ followed by selective formylation at the 1-position (Reimer-Tiemann reaction) ${ }^{26)}$ yielded the desired phenolic<smiles></smiles><smiles>CCC(=O)N1CCc2c(ccc3c(I)cc(OC)cc23)N1</smiles><smiles>CCC(=O)N1CCc2c(ccc3ccc(OC)cc23)N1</smiles><smiles>CCC(=O)NCCc1c(OC)ccc2ccccc12</smiles>

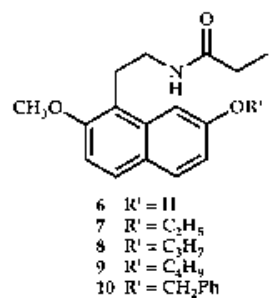

Fig. 1. Structures of Compounds $\mathbf{1}-\mathbf{1 0}$ 
<smiles>COc1ccc2ccc(OCc3ccccc3)cc2c1C=O</smiles><smiles>CCC(=O)N1CCc2c(OC)ccc3ccc(O)c(c23)N1C(=O)CC</smiles>

Fig. 2. Synthesis of Compounds $\mathbf{6}-\mathbf{1 0}$

Reagents and Conditions: a. $\mathrm{PhCH}_{2} \mathrm{Br}, \mathrm{K}_{2} \mathrm{CO}_{3}$, acetone, reflux, 4 h, 39\%; b. i) $\mathrm{NaOH}, \mathrm{CHCl}_{3}$, $\mathrm{H}_{2} \mathrm{O}$, reflux, $2 \mathrm{~h}$; ii) $\mathrm{H}_{3} \mathrm{O}^{+}, 14 \%$; c. $\mathrm{CH}_{3} \mathrm{I}$, $\mathrm{K}_{2} \mathrm{CO}_{3}$, acetone, reflux, 20 h, $95 \%$; d. $\mathrm{CH}_{3} \mathrm{NO}_{2}, \mathrm{NH}_{4} \mathrm{OAc}$, reflux, $4 \mathrm{~h}, 100 \%$; e. i) $\mathrm{LiAlH}_{4}, \mathrm{THF}, 40{ }^{\circ} \mathrm{C}, 18 \mathrm{~h}$; ii) $\mathrm{C}_{2} \mathrm{H}_{5} \mathrm{COCl}, \mathrm{Et}_{3} \mathrm{~N}, \mathrm{CH}_{2} \mathrm{Cl}_{2}$, r.t., 1 h, $63 \%$; f. $10 \% \mathrm{Pd}-\mathrm{C}, \mathrm{MeOH}, \mathrm{H}_{2}$, r.t., 18 h, $100 \%$; g. RI $\left(\mathrm{R}=\mathrm{C}_{2} \mathrm{H}_{5}, \mathrm{C}_{3} \mathrm{H}_{7}\right.$, $\left.\mathrm{C}_{4} \mathrm{H}_{9}\right), \mathrm{K}_{2} \mathrm{CO}_{3}$, acetone, reflux, $18 \mathrm{~h}, 76-94 \%$.

aldehyde 13 (14\%). The structure of 13 was confirmed unambiguously by ${ }^{1} \mathrm{H}$-NMR spectra in which four protons have a large coupling constant of $9.0 \mathrm{~Hz}$ and the proton of $\mathrm{OH}$ moved downfield to $13.15 \mathrm{ppm}$. Methylation of $\mathbf{1 3}$ with methyl iodide formed $\mathbf{1 4}$ which was condensed with nitromethane in the presence of $\mathrm{NH}_{4} \mathrm{OAc}$ to furnish nitroalkene 15 (95\% yield in 2 steps). Reduction of $\mathbf{1 5}$ with $\mathrm{LiAlH}_{4}$ followed by acylation with propionyl chloride afforded amide $10(63 \%$ yield based on 15). The benzyl group in $\mathbf{1 0}$ was removed in $\mathrm{Pd}-\mathrm{H}_{2}$ to give phenol $6(100 \%)$. Treatment of 6 with various alkyl iodides yielded the corresponding alkylated products 7-9 (76-94\% yield).

Melatonin Receptors Ligands' Binding Affinity The affinities of compounds $\mathbf{6}-\mathbf{1 0}$ for melatonin receptors were evaluated in vitro and in duplicate by competition binding analysis using the radioligand $2-\left[{ }^{125} \mathrm{I}\right]$-iodomelatonin $(80-$ 100 pm; DuPont, Boston, MA, U.S.A.) as described previously. ${ }^{27)}$ The competition binding assays were performed 3 5 times for each compound. The affinity of 2-[ $\left.{ }^{125} \mathrm{I}\right]$-iodomelatonin for the $\mathrm{MT}_{1}$ and $\mathrm{MT}_{2}$ melatonin receptors was 80 and $150 \mathrm{pm}$, respectively. To ensure that the affinities of compounds 6-10 for the melatonin receptors were not artifact, these compounds, like melatonin, were dissolved in ethanol, the pipette tips were changed in between serial dilutions, and melatonin competition curves were run in parallel with every compound tested. As shown in Table 1, compounds 6-10 displayed higher affinity than melatonin and exhibited subpicomolar binding affinities to both $\mathrm{MT}_{1}$ and $\mathrm{MT}_{2}$ receptors. The affinity of these compounds for the melatonin receptors increased from $0.85 \mathrm{pm}$ to $<0.01 \mathrm{pM}$ as the $\mathrm{R}^{\prime}$ substituent increased from $\mathrm{H}$ to $n$-Bu. A further increase in size of the $\mathrm{R}^{\prime}$ substituent (benzyl) resulted in a decrease in binding affinity. However, this is in complete contrast to the affinities of compound 4 for $\mathrm{MT}_{1}$ and $\mathrm{MT}_{2}$ melatonin receptors in regard to varying the size of the $R^{\prime}$ substituent. In compound 4 , the compound with the highest affinity to both $\mathrm{MT}_{1}$ and $\mathrm{MT}_{2}$ receptors are $\mathrm{R}^{\prime}=\mathrm{CH}_{3}$ and $\mathrm{C}_{2} \mathrm{H}_{5}$. Any increase in size in the $\mathrm{R}^{\prime}$ substituent results in a decrease in binding affinity. ${ }^{16)}$ It has been stated that the 5-methoxy group in melatonin is involved in critical hydrogen bonding to the receptor recognition site. ${ }^{28)}$ If it is assumed that the methoxy group in compound 4 mimics the 5-methoxy group of melatonin, then
Table 1. Competition of Melatonin and Substituted Naphthalene for 2$\left[{ }^{125} \mathrm{I}\right]$-iodomelatonin Binding to Human $\mathrm{MT}_{1}$ or $\mathrm{MT}_{2}$ Melatonin Receptors Stably Expressed in CHO Cells

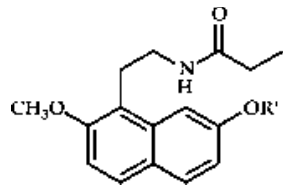

\begin{tabular}{|c|c|c|c|}
\hline \multirow{2}{*}{ Compound \# } & \multicolumn{3}{|c|}{$K_{\mathrm{i}}($ range of SEM) } \\
\hline & $\mathrm{R}^{\prime}$ & $\mathrm{MT}_{1}$ & $\mathrm{MT}_{2}$ \\
\hline 6 & $\mathrm{H}$ & 0.85 рм $(0.42-1.7)$ & 0.62 рм $(0.15-2.6)$ \\
\hline 7 & $\mathrm{C}_{2} \mathrm{H}_{5}$ & 0.15 рм $(0.023-1.0)$ & 20 рм $(5.6-68)$ \\
\hline 8 & $\mathrm{C}_{3} \mathrm{H}_{7}$ & $<0.01 \mathrm{pM}$ & $<0.01 \mathrm{pM}$ \\
\hline 9 & $\mathrm{C}_{4} \mathrm{H}_{9}$ & $<0.01 \mathrm{pm}$ & $<0.01 \mathrm{pm}$ \\
\hline 10 & $\mathrm{CH}_{2} \mathrm{Ph}$ & $0.38 \mathrm{pm}(0.05-2.5)$ & 0.12 рм $(0.039-0.47)$ \\
\hline Melatonin & & $12 \mathrm{pм}(4.2-35)$ & $3.0 \mathrm{pм}(1.2-7.7)$ \\
\hline
\end{tabular}

transferring the amidoethyl group from $\mathrm{C} 1$ to $\mathrm{C} 8$ eliminated the steric interference between the amidoethyl group and the 2 substituent in compound $\mathbf{4}$ and resulted in an increase in binding affinity to both $\mathrm{MT}_{1}$ and $\mathrm{MT}_{2}$ receptors.

In conclusion, A series of $N$-[2-(7-alkoxy-2-methoxy-1naphthyl)ethyl]propionamides were prepared and their binding affinities on both $\mathrm{MT}_{1}$ and $\mathrm{MT}_{2}$ melatonin receptors were evaluated. The analogs exhibit high binding affinities to the receptors and the affinity of these compounds for the melatonin receptors decreased from $0.85 \mathrm{pm}$ to $<0.01 \mathrm{pm}$ as the $\mathrm{R}^{\prime}$ substituent increased from $\mathrm{H}$ to $n$-Bu. A further increase in size of the $\mathrm{R}^{\prime}$ substituent (benzyl) resulted in a decrease in binding affinity.

\section{Experimental}

The Preparation of 7-(Benzyloxy)-2-naphthol (12) To a solution of $20.8 \mathrm{~g}(130 \mathrm{mmol})$ of 2,7-dihydroxynaphthalene $\mathbf{1 1}$ was added $15.2 \mathrm{~g}$ $(110 \mathrm{mmol})$ of benzyl bromide. The reaction mixture was refluxed for $4 \mathrm{~h}$ and cooled to room temperature (r.t.). The reaction mixture was filtered and the filtrate was concentrated in vacuo. The residue was purified by column chromatography on silica gel using $\mathrm{CH}_{2} \mathrm{Cl}_{2}$-petroleum ether $(4: 1)$ as eluent, giving $10.8 \mathrm{~g} \mathrm{(39 \% )}$ of monobenzylated product $12 ; \mathrm{mp} 151.5-152{ }^{\circ} \mathrm{C} ;{ }^{1} \mathrm{H}-$ NMR $\left(300 \mathrm{MHz}\right.$, DMSO- $\left.d_{6}\right) \delta 5.17\left(\mathrm{~s}, 2 \mathrm{H}, \mathrm{PhCH}_{2}\right), 6.89-6.99(\mathrm{~m}, 2 \mathrm{H}$, $\operatorname{ArH}), 7.03(\mathrm{~d}, 1 \mathrm{H}, J=2.1 \mathrm{~Hz}, \operatorname{ArH}), 7.20(\mathrm{~d}, 1 \mathrm{H}, J=2.1 \mathrm{~Hz}, \mathrm{ArH}), 7.31-$ $7.68(\mathrm{~m}, 7 \mathrm{H}, \mathrm{ArH}), 9.66(\mathrm{~s}, 1 \mathrm{H}, \mathrm{OH})$. Anal. Calcd for $\mathrm{C}_{17} \mathrm{H}_{14} \mathrm{O}_{2}: \mathrm{C}, 81.58 ; \mathrm{H}$, 5.64. Found: C, 81.62; H, 5.47. 
The Preparation of 7-(Benzyloxy)-2-hydroxy-1-naphthylaldehyde (13) 7-Benzyloxy-2-naphthol $\mathbf{1 2}(5.0 \mathrm{~g}, 20 \mathrm{mmol})$ was added to a solution of $\mathrm{NaOH}(6.4 \mathrm{~g}, 0.16 \mathrm{~mol})$ in $40 \mathrm{ml}$ of water and the mixture was heated to $65-70^{\circ} \mathrm{C}$. Chloroform $(3.6 \mathrm{ml}, 44.8 \mathrm{mmol})$ was added to the mixture in three portions at intervals of $15 \mathrm{~min}$. After the addition of $\mathrm{CHCl}_{3}$, the reaction mixture was stirred at $100^{\circ} \mathrm{C}$ for $1 \mathrm{~h}$. After cooling, the reaction mixture was acidified with diluted sulfuric acid and then extracted with $\mathrm{CH}_{2} \mathrm{Cl}_{2}$ $(3 \times 60 \mathrm{ml})$. The organic extracts were dried $\left(\mathrm{Na}_{2} \mathrm{SO}_{4}\right)$ and evaporated. The residue was purified by silica gel chromatography using $\mathrm{CH}_{2} \mathrm{Cl}_{2}$-petroleum ether $(3: 1)$ as eluent, yielding $0.75 \mathrm{~g}(14 \%)$ of pure aldehyde 13. mp $125-$ $126.5^{\circ} \mathrm{C}$; ${ }^{1} \mathrm{H}-\mathrm{NMR}\left(300 \mathrm{MHz}, \mathrm{CDCl}_{3}\right) \delta 5.20\left(\mathrm{~s}, 2 \mathrm{H}, \mathrm{PhCH}_{2}\right), 6.95(\mathrm{~d}, 1 \mathrm{H}$, $J=9.0 \mathrm{~Hz}, \mathrm{ArH}), 7.13$ (dd, $1 \mathrm{H}, J=2.1,9.0 \mathrm{~Hz}, \mathrm{ArH}), 7.43$ (m, 5H, ArH), $7.69(\mathrm{~d}, 1 \mathrm{H}, J=9.0 \mathrm{~Hz}, \operatorname{ArH}) 7.72(\mathrm{~d}, 1 \mathrm{H}, J=2.1 \mathrm{~Hz}, \operatorname{ArH}), 7.86(\mathrm{~d}, 1 \mathrm{H}$, $J=9.0 \mathrm{~Hz}, \mathrm{ArH}), 10.65$ (s, 1H, CHO), $13.15\left(\mathrm{~s}, 1 \mathrm{H}, \mathrm{OH}, \mathrm{D}_{2} \mathrm{O}\right.$ exchangeable). Anal. Calcd for $\mathrm{C}_{18} \mathrm{H}_{14} \mathrm{O}_{3}: \mathrm{C}, 77.68 ; \mathrm{H}, 5.07$. Found: C, 77.46; H, 5.38 .

The Preparation of 7-(Benzyloxy)-2-methoxy-1-naphthylaldehyde (14) To a solution of the aldehyde $\mathbf{1 3}(1.6 \mathrm{~g}, 5.76 \mathrm{mmol})$ in dry acetone $(60 \mathrm{ml})$ was added methyl iodide $\left(\mathrm{CH}_{3} \mathrm{I}, 1.2 \mathrm{ml}, 19.3 \mathrm{mmol}\right)$ and $\mathrm{K}_{2} \mathrm{CO}_{3}(1.2 \mathrm{~g}$, $8.7 \mathrm{mmol}$ ). The reaction mixture was refluxed for $20 \mathrm{~h}$ and then filtered to remove the inorganic salt. Concentration of the filtrate gave the crude product (as a solid) which was washed with petroleum ether to remove excess methyl iodide furnishing $1.88 \mathrm{~g} \mathrm{(95 \% )}$ of pure $\mathbf{1 4}$ after silica gel column chromatography (petroleum ether $\left./ \mathrm{CH}_{2} \mathrm{Cl}_{2}, 1: 2\right)$. mp $111.5-112.5^{\circ} \mathrm{C} ;{ }^{1} \mathrm{H}-\mathrm{NMR}(300$ $\left.\mathrm{MHz}, \mathrm{CDCl}_{3}\right) \delta 4.01\left(\mathrm{~s}, 3 \mathrm{H}, \mathrm{OCH}_{3}\right), 5.22\left(\mathrm{~s}, 2 \mathrm{H}, \mathrm{CH}_{2} \mathrm{Ph}\right), 7.07-7.53(\mathrm{~m}$, $7 \mathrm{H}, \mathrm{ArH}), 7.65$ (d, $1 \mathrm{H}, J=9.0 \mathrm{~Hz}, \mathrm{ArH}), 7.95(\mathrm{~d}, 1 \mathrm{H}, J=9.0 \mathrm{~Hz}, \mathrm{ArH}), 8.95$ (d, $1 \mathrm{H}, J=2.3 \mathrm{~Hz}, \mathrm{ArH}), 10.87$ (s, $1 \mathrm{H}, \mathrm{CHO}$ ). Anal. Calcd for $\mathrm{C}_{19} \mathrm{H}_{16} \mathrm{O}_{3}: \mathrm{C}$, 78.06; H, 5.52. Found: C, 78.03; H, 5.62.

The Preparation of 7-(Benzyloxy)-2-methoxy-1-[(E)-2-nitroethenyl]naphthalene (15) A solution of the aldehyde $14(1.72 \mathrm{~g}, 5.9 \mathrm{mmol})$ and ammonium acetate $(0.3 \mathrm{~g}, 3.9 \mathrm{mmol})$ in nitromethane $(18.4 \mathrm{ml})$ was refluxed for $4 \mathrm{~h}$. After evaporation of the solvent in vacuo, the residue was dissolved in $\mathrm{CH}_{2} \mathrm{Cl}_{2}(30 \mathrm{ml})$ and $\mathrm{H}_{2} \mathrm{O}(25 \mathrm{ml})$ was added. The organic layer was separated and the aqueous layer was extracted with $\mathrm{CH}_{2} \mathrm{Cl}_{2}(2 \times 25 \mathrm{ml})$. The combined organic extracts were washed with $\mathrm{H}_{2} \mathrm{O}(30 \mathrm{ml})$ and then dried $\left(\mathrm{Na}_{2} \mathrm{SO}_{4}\right)$. Evaporation of the solvent under reduced pressure gave $1.97 \mathrm{~g}$ $(\sim 100 \%)$ of pure product $15 ; \mathrm{mp} 163-164.5^{\circ} \mathrm{C}$; ${ }^{1} \mathrm{H}-\mathrm{NMR}(300 \mathrm{MHz}$, $\left.\mathrm{CDCl}_{3}\right) \delta 4.05\left(\mathrm{~s}, 3 \mathrm{H}, \mathrm{OCH}_{3}\right), 5.28\left(\mathrm{~s}, 2 \mathrm{H}, \mathrm{CH}_{2} \mathrm{Ph}\right), 7.07(\mathrm{~d}, 1 \mathrm{H}, J=9.0 \mathrm{~Hz}$, ArH), 7.14 (dd, $1 \mathrm{H}, J=2.4,9.0 \mathrm{~Hz}, \mathrm{ArH}), 7.33-7.53(\mathrm{~m}, 6 \mathrm{H}, \mathrm{ArH}), 7.70$ (d, $1 \mathrm{H}, J=9.0 \mathrm{~Hz}, \mathrm{ArH}), 7.85(\mathrm{~d}, 1 \mathrm{H}, J=9.0 \mathrm{~Hz}, \mathrm{ArH}), 8.08(\mathrm{~d}, 1 \mathrm{H}, J=13.2 \mathrm{~Hz}$, $\left.\mathrm{CHNO}_{2}\right), 8.68(\mathrm{~d}, 1 \mathrm{H}, J=13.2 \mathrm{~Hz}, \mathrm{ArH})$. Anal. Calcd for $\mathrm{C}_{20} \mathrm{H}_{17} \mathrm{NO}_{4}: \mathrm{C}$, 71.63; H, 5.11; N, 4.18. Found: C, 71.82; H, 5.03; N, 4.26.

The Preparation of $\mathrm{N}$-[2-(7-(Benzyloxy)-2-methoxy-1-naphthyl)ethyl]propionamide (10) To a stirred suspension of $\mathrm{LiAlH}_{4}(1.0 \mathrm{~g}, 26.3 \mathrm{mmol})$ in anhydrous tetrahydrofuran (THF) $(60 \mathrm{ml})$ at $0{ }^{\circ} \mathrm{C}$ was added dropwise a solution of compound $15(1.5 \mathrm{~g}, 4.48 \mathrm{mmol})$ in THF $(20 \mathrm{ml})$. The reaction mixture was stirred at $40^{\circ} \mathrm{C}$ for $18 \mathrm{~h}$ and then cooled to $0{ }^{\circ} \mathrm{C}$. Solutions were then added to the mixture in the following order: $\mathrm{H}_{2} \mathrm{O}(1.0 \mathrm{ml}), 15 \% \mathrm{NaOH}$ solution $(1.0 \mathrm{ml})$, EtOAc $(50 \mathrm{ml})$ and $\mathrm{H}_{2} \mathrm{O}(30 \mathrm{ml})$. The mixture was filtered, and the filtrate was dried $\left(\mathrm{Na}_{2} \mathrm{SO}_{4}\right)$. The solvent was evaporated in vacuo and the crude product thus obtained was dried overnight in vacuo and used for the next step without further purification.

To a solution of the above crude product in anhydrous $\mathrm{CH}_{2} \mathrm{Cl}_{2}(25 \mathrm{ml})$ at $0{ }^{\circ} \mathrm{C}$ were added triethylamine $(1.2 \mathrm{ml}, 8.6 \mathrm{mmol})$ in one portion and then propionyl chloride $(0.5 \mathrm{ml}, 5.72 \mathrm{mmol})$ dropwise. The reaction mixture was stirred at r.t. for $1 \mathrm{~h}$ and was diluted with $\mathrm{CH}_{2} \mathrm{Cl}_{2}(30 \mathrm{ml})$, washed with saturated $\mathrm{NaHCO}_{3}$ solution $(20 \mathrm{ml})$ and $\mathrm{H}_{2} \mathrm{O}(20 \mathrm{ml})$. The organic layer was dried $\left(\mathrm{Na}_{2} \mathrm{SO}_{4}\right)$ and concentrated. The residue was purified by silica gel chromatography using petroleum ether:EtOAc $(1: 1)$ as eluent, yielding $880 \mathrm{mg}(54 \%$ based on compound 15$)$ of amide $10 ; \mathrm{mp} 121.5-122.5^{\circ} \mathrm{C}$; ${ }^{1} \mathrm{H}-\mathrm{NMR}\left(300 \mathrm{MHz}, \mathrm{CDCl}_{3}\right) \delta 1.06\left(\mathrm{t}, 3 \mathrm{H}, J=7.5 \mathrm{~Hz}, \mathrm{CH}_{3}\right), 2.10(\mathrm{q}, 2 \mathrm{H}$, $\left.J=7.5 \mathrm{~Hz}, \mathrm{CH}_{2} \mathrm{CO}\right), 3.23\left(\mathrm{t}, 2 \mathrm{H}, J=6.9 \mathrm{~Hz}, \mathrm{ArCH}_{2}\right), 3.50\left(\mathrm{~m}, 2 \mathrm{H}, \mathrm{CH}_{2} \mathrm{~N}\right)$, $3.93\left(\mathrm{~s}, 3 \mathrm{H}, \mathrm{OCH}_{3}\right), 5.22\left(\mathrm{~s}, 2 \mathrm{H}, \mathrm{CH}_{2} \mathrm{Ph}\right), 5.76(\mathrm{br} \mathrm{s}, 1 \mathrm{H}, \mathrm{NH}), 7.08(\mathrm{dd}, 1 \mathrm{H}$, $J=2.4,9.0 \mathrm{~Hz}, \mathrm{ArH}), 7.10(\mathrm{~d}, 1 \mathrm{H}, J=9.0 \mathrm{~Hz}, \mathrm{ArH}), 7.32-7.50(\mathrm{~m}, 6 \mathrm{H}$, ArH), 7.67 (d, $1 \mathrm{H}, J=9.0 \mathrm{~Hz}, \operatorname{ArH}), 7.68$ (d, $1 \mathrm{H}, J=9.0 \mathrm{~Hz}, \mathrm{ArH})$. Anal. Calcd for $\mathrm{C}_{23} \mathrm{H}_{25} \mathrm{NO}_{3}$ : C, 76.01; H, 6.93; N, 3.85. Found: C, 76.15; H, 6.82; N, 3.96 .

The Preparation of $\mathrm{N}$-[2-(7-Hydroxy-2-methoxy-1-naphthyl)ethyl]propionamide (6) Amide $\mathbf{1 0}(1.2 \mathrm{~g}, 3.3 \mathrm{mmol})$ in methanol $(38 \mathrm{ml})$ was hydrogenated over $10 \% \mathrm{Pd}$ on activated carbon at r.t. for $18 \mathrm{~h}$. The reaction mixture was filtered through celite. The filtrate was concentrated and purified by silica gel chromatography using petroleum ether-EtOAc $(1: 2)$ as eluent, yielding $0.9 \mathrm{~g}(\sim 100 \%)$ of compound $\mathbf{6}$; mp $118-120{ }^{\circ} \mathrm{C}$; ${ }^{1} \mathrm{H}-\mathrm{NMR}$ $\left(300 \mathrm{MHz}, \mathrm{CDCl}_{3}\right) \delta 1.02\left(\mathrm{t}, 3 \mathrm{H}, J=7.5 \mathrm{~Hz}, \mathrm{CH}_{3}\right), 2.07(\mathrm{q}, 2 \mathrm{H}, J=7.5 \mathrm{~Hz}$, $\left.\mathrm{CH}_{2} \mathrm{CO}\right), 3.03\left(\mathrm{t}, 2 \mathrm{H}, J=6.6 \mathrm{~Hz}, \mathrm{ArCH}_{2}\right) 3.18\left(\mathrm{~m}, 2 \mathrm{H}, \mathrm{CH}_{2} \mathrm{~N}\right), 3.87(\mathrm{~s}, 3 \mathrm{H}$,
$\left.\mathrm{OCH}_{3}\right), 6.92(\mathrm{dd}, 1 \mathrm{H}, J=1.8,9.0 \mathrm{~Hz}, \mathrm{ArH}), 7.16(\mathrm{~d}, 1 \mathrm{H}, J=9.0 \mathrm{~Hz}, \mathrm{ArH})$, $7.23(\mathrm{~d}, 1 \mathrm{H}, J=1.8 \mathrm{~Hz}, \mathrm{ArH}), 7.68$ (d, $2 \mathrm{H}, J=9.0 \mathrm{~Hz}, \mathrm{ArH}), 7.92$ (brt, $1 \mathrm{H}$, $J=5.1 \mathrm{~Hz}, \mathrm{ArH}), 9.64(\mathrm{~s}, 1 \mathrm{H}, \mathrm{OH})$. Anal. Calcd for $\mathrm{C}_{16} \mathrm{H}_{19} \mathrm{NO}_{3}: \mathrm{C}, 70.31 ; \mathrm{H}$, 7.01; N, 5.12. Found: C, 70.42; H, 6.87; N, 4.98.

The Preparation of $\mathrm{N}$-[2-(7-Ethoxy-2-methoxy-1-naphthyl)ethyl]propionamide (7) To a solution of phenol $6(100 \mathrm{mg}, 0.366 \mathrm{mmol})$ in acetone $(6 \mathrm{ml})$ was added $\mathrm{K}_{2} \mathrm{CO}_{3}$ (76 mg, $0.55 \mathrm{mmol}$ ) followed by ethyl iodide $(0.12 \mathrm{ml}, 1.5 \mathrm{mmol})$. The reaction mixture was refluxed for $18 \mathrm{~h}$ and then cooled, filtered. The filtrate was concentrated in vacuo and the residue was purified by flash chromatography using ethyl acetate-methylene chloride $(1: 1)$ as the eluent, yielding pure $7(95 \mathrm{mg}, 86 \%)$; mp $119-120.5^{\circ} \mathrm{C} ;{ }^{1} \mathrm{H}-$ NMR $\left(300 \mathrm{MHz}, \mathrm{CDCl}_{3}\right) \delta 1.06\left(\mathrm{t}, 3 \mathrm{H}, J=7.5 \mathrm{~Hz}, \mathrm{CH}_{3}\right), 1.47$ (t, $3 \mathrm{H}$, $\left.J=6.9 \mathrm{~Hz}, \mathrm{CH}_{3}\right), 2.10\left(\mathrm{q}, 2 \mathrm{H}, J=7.5 \mathrm{~Hz}, \mathrm{CH}_{2} \mathrm{CO}\right), 3.25(\mathrm{t}, 2 \mathrm{H}, J=6.7 \mathrm{~Hz}$, $\left.\mathrm{ArCH}_{2}\right), 3.53\left(\mathrm{~m}, 2 \mathrm{H}, \mathrm{CH}_{2} \mathrm{~N}\right), 3.93\left(\mathrm{~s}, 3 \mathrm{H}, \mathrm{OCH}_{3}\right), 4.17(\mathrm{q}, 2 \mathrm{H}, J=6.9 \mathrm{~Hz}$, $\left.\mathrm{CH}_{2} \mathrm{O}\right), 5.79(\mathrm{br} \mathrm{s}, 1 \mathrm{H}, \mathrm{NH}), 6.99(\mathrm{dd}, 1 \mathrm{H}, J=2.1,9.0 \mathrm{~Hz}, \mathrm{ArH}), 7.09(\mathrm{~d}, 1 \mathrm{H}$, $J=9.0 \mathrm{~Hz}, \mathrm{ArH}), 7.26(\mathrm{~d}, 1 \mathrm{H}, J=2.1 \mathrm{~Hz}, \mathrm{ArH}), 7.66(\mathrm{~d}, 2 \mathrm{H}, J=9.0 \mathrm{~Hz}, \mathrm{ArH})$. Anal. Calcd for $\mathrm{C}_{18} \mathrm{H}_{23} \mathrm{NO}_{3}: \mathrm{C}, 71.73 ; \mathrm{H}, 7.69 ; \mathrm{N}, 4.65$. Found: $\mathrm{C}, 71.52 ; \mathrm{H}$, $7.73 ; \mathrm{N}, 4.53$.

The Preparation of $N$-[2-(2-Methoxy-7-propoxy-1-naphthyl)ethyl]propionamide (8) The synthesis of compound $\mathbf{8}$ is similar to the procedure for the synthesis of 7 using $n$-propyl iodide instead of iodoethane $(94 \%$ yield); mp $111-112.5^{\circ} \mathrm{C} ;{ }^{1} \mathrm{H}-\mathrm{NMR}\left(300 \mathrm{MHz}, \mathrm{CDCl}_{3}\right) \delta 1.07(\mathrm{~m}, 6 \mathrm{H}$, $\left.2 \times \mathrm{CH}_{3}\right), 1.86\left(\mathrm{~m}, 2 \mathrm{H}, \mathrm{CH}_{2}\right), 2.09\left(\mathrm{q}, 2 \mathrm{H}, J=7.5 \mathrm{~Hz}, \mathrm{CH}_{2} \mathrm{CO}\right), 3.26(\mathrm{t}, 2 \mathrm{H}$, $\left.J=6.6 \mathrm{~Hz}, \mathrm{ArCH}_{2}\right), 3.53\left(\mathrm{~m}, 2 \mathrm{H}, \mathrm{CH}_{2} \mathrm{~N}\right), 3.93\left(\mathrm{~s}, 3 \mathrm{H}, \mathrm{OCH}_{3}\right), 4.05(\mathrm{t}, 2 \mathrm{H}$, $\left.J=6.3 \mathrm{~Hz}, \mathrm{CH}_{2} \mathrm{O}\right), 5.79(\mathrm{br} \mathrm{s}, 1 \mathrm{H}, \mathrm{NH}), 6.99(\mathrm{dd}, 1 \mathrm{H}, J=2.1,9.0 \mathrm{~Hz}, \mathrm{ArH})$, 7.09 (d, $1 \mathrm{H}, J=9.0 \mathrm{~Hz}, \mathrm{ArH}), 7.25(\mathrm{~d}, 1 \mathrm{H}, J=2.1 \mathrm{~Hz}, \mathrm{ArH}), 7.66(\mathrm{~d}, 2 \mathrm{H}$, $J=9.0 \mathrm{~Hz}$, ArH). Anal. Calcd for $\mathrm{C}_{19} \mathrm{H}_{25} \mathrm{NO}_{3}: \mathrm{C}, 72.35 ; \mathrm{H}, 7.99 ; \mathrm{N}, 4.44$. Found: C, 72.63; H, 7.87; N, 4.51.

The Preparation of $N$-[2-(7-Butoxy-2-methoxy-1-naphthyl)ethyl]propionamide (9) The synthesis of compound 9 is similar to the procedure for the synthesis of 7 using $n$-butyl iodide instead of iodoethane $(76 \%$ yield); mp 92-93 ${ }^{\circ} \mathrm{C} ;{ }^{1} \mathrm{H}-\mathrm{NMR}\left(300 \mathrm{MHz}, \mathrm{CDCl}_{3}\right) \delta 0.99$ (t, $3 \mathrm{H}, J=7.5 \mathrm{~Hz}$, $\left.\mathrm{CH}_{3}\right), 1.53\left(\mathrm{~m}, 2 \mathrm{H}, \mathrm{CH}_{2}\right), 1.84\left(\mathrm{~m}, 2 \mathrm{H}, \mathrm{CH}_{2}\right), 2.09(\mathrm{q}, 2 \mathrm{H}, J=7.5 \mathrm{~Hz}$, $\left.\mathrm{CH}_{2} \mathrm{CO}\right), 3.26\left(\mathrm{t}, 2 \mathrm{H}, J=6.6 \mathrm{~Hz}, \mathrm{ArCH}_{2}\right), 3.54\left(\mathrm{~m}, 2 \mathrm{H}, \mathrm{CH}_{2} \mathrm{~N}\right), 3.93(\mathrm{~s}, 3 \mathrm{H}$, $\left.\mathrm{OCH}_{3}\right), 4.09\left(\mathrm{t}, 2 \mathrm{H}, J=6.3 \mathrm{~Hz}, \mathrm{CH}_{2} \mathrm{O}\right), 5.80(\mathrm{br} \mathrm{s}, 1 \mathrm{H}, \mathrm{NH}), 6.99(\mathrm{dd}, 1 \mathrm{H}$, $J=2.1,9.0 \mathrm{~Hz}, \mathrm{ArH}), 7.09(\mathrm{~d}, 1 \mathrm{H}, J=9.0 \mathrm{~Hz}, \mathrm{ArH}), 7.25(\mathrm{~d}, 1 \mathrm{H}, J=2.1 \mathrm{~Hz}$, ArH), $7.66(\mathrm{~d}, 2 \mathrm{H}, J=9.0 \mathrm{~Hz}, \mathrm{ArH})$. Anal. Calcd for $\mathrm{C}_{20} \mathrm{H}_{27} \mathrm{NO}_{3}$ : C, 72.92 ; $\mathrm{H}, 8.26$; N, 4.25. Found: C, 72.88; H, 8.19; N, 4.31.

Acknowledgement This research is supported in part by NIH R1538873.

\section{References}

1) Morgan P. J., Barrett P., Howell H. E., Helliwell R., Neurochem. Int., 24, 101-146 (1994).

2) Dubocovich M. L., Trends Pharmacol. Sci., 16, 50-56 (1995).

3) Krause D. N., Barrios V. E., Duckles S. P., Eur. J. Pharmacol., 276, 207-213 (1995).

4) Brzezinski A., N. Engl. J. Med., 336, 186-195 (1997).

5) Ting K. N., Dunn W. R., Davies D. J., Sugden D., Delagrange P., Guardiola-Lemaitre B., Scalbert E., Wilson V. G., Br. J. Pharmacology, 122, 1299-1306 (1997).

6) Gozzo A., Lesieur D., Duriez P., Fruchart J. C., Teissier E., Free Radic. Biol. Med., 26, 1538-1543 (1999).

7) Bucher B., Gauer F., Pevet P., Masson-Pevet M., J. Cardiovasc. Pharmacol., 33, 316-322 (1999).

8) Dubocovich M. L., Cardinali D. P., Guardiola-Lemaitre R. M., Hagan R. M., Krause D. N., Sugden D., Vanhoutte P. M., Yocca F. D., "The IUPHAR Compendium of Receptor Characterization and Classification IUPHAR Media," London, 1998, pp. 187-193.

9) Reppert S. M., Weaver D. R., Ebisawa T., Neuron, 13, 1177-1185 (1994).

10) Reppert S. M., Godson C., Mahle C. D., Weaver D. R., Slaugenhaupt S. A., Gusella, J. F., Proc. Natl. Acad. Sci., 92, 8734 -8738 (1995).

11) Yous S., Andrieux J., Howell H. E., Morgan P. J., Renard P., Pfeiffer B., Lesieur D., Guardiola-Lemaitre B., J. Med. Chem., 35, 1484-1486 (1992).

12) Langlois M., Bremont B., Shen S., Poncet A., Andrieux J., Sicsic S., Serraz I., Mathe-Allainmat M., Renard P., Delagrange P., J. Med. Chem., 38, 2050-2060 (1995).

13) Leclerc V., Depreux P., Lesieur D., Caignard D. H., Renard P., Delagrange P., Buardiola-Lemaitre B., Morgan, P., Bioorg. \& Med. Chem. Lett., 6, 1071-1076 (1996).

14) Mathe-Allainmat M., Andrieux J., Langlois M., Exp. Opin. Ther. 
Patents, 7, 1447-1458 (1997).

15) Pang C. S., Tang P. L., Song Y., Pang S. F., Ng K. W., GuardiolaLemaitre B., Delagrange P., Brown G. M., J. Pineal Res., 23, 148155 (1997).

16) Li P. K., Chu G. H., Gillen M. L., Parekh T., Witt-Enderby P. A., Bioorg. \& Med. Chem. Lett., 7, 2409-2414 (1997).

17) Witt-Enderby P. A., Chu G. H., Gillen M. L., Li P. K., J. Med. Chem., 40, 4195-4198 (1997).

18) Leclerc V., Fourmaintraux E., Dupreux P., Lesieur D., Morgan M., Howell H. E., Renard P., Caignard D. H., Pfeiffer B., Delagrange P., Guardiola-Lemaitre B., Andrieux J., Bioorg. \& Med. Chem., 6, 18751887 (1998).

19) Masson-Pevet M., Recio J., Guerrero H. Y., Mocaer E., Delagrange P., Guardiola-Lemaitre B., Pevet P., J. Pineal Res., 25, 172-176 (1998).

20) Andries V., Depreux P., Synth. Commun., 27, 4207-4214 (1997).

21) Copinga S., Tepper P. G., Grol C. J., Horn A. S., Dubocovich M. L., J.
Med. Chem., 36, 2891-2898 (1993).

22) Sugden D., Eur. J. Pharmacol., 254, 271-275 (1994).

23) Jansen J. M., Copinga S., Gruppen G., Molinar E. J., Dubocovich M. L., Grol C. J., Bioorg. \& Med. Chem., 4, 1321-1332 (1996).

24) Depreux P., Lesieur D., Mansour H. A., Morgan P., Howell H. E., Renard P., Caignard D. H., Pfeiffer B., Delagrange P., Guardiola B., Yous S., Demarque A., Adam G., Andrieux J., J. Med. Chem., 37, 32313239 (1994).

25) Li P. K., Chu G. H., Gillen M. L., Witt-Enderby P. A., Bioorg. \& Med. Chem. Lett., 7, 2177-2180 (1997).

26) Wynberg H., Chem. Rev., 60, 169-184 (1960).

27) Witt-Enderby P. A., Dubocovich M. L., Mol. Pharmacol., 50, 166174 (1996).

28) Sugden D., Chong N. W. S., Lewis D. F. V., Br. J. Pharmacol., 114, 618-623(1995). 